\title{
METHODOLOGY TO ASSESS WATER PRESENCE ON SPELEOTHEMS DURING PERIODS OF LOW PRECIPITATION, WITH IMPLICATIONS FOR RECHARGE SOURCES - KARTCHNER CAVERNS, ARIZONA
}

\author{
Kyle W. Blasch \\ Montana Water Science Center, U.S. Geological Survey, 3162 Bozeman Ave., Helena, Montana 59601, kblasch@usgs.gov
}

\begin{abstract}
Beginning in January 2005, recharge processes and the presence of water on speleothems were monitored in Kartchner Caverns during a 44-month period when annual rainfall rates were 6 to 18 percent below the long-term mean. Electrical-resistance sensors designed to detect the presence of water were used to identify ephemeral streamflow in the channels overlying the cave as well as the movement of water within the cave system. Direct infiltration of precipitation through overhead rocks provided consistent inflow to the cave, but precipitation rates and subsequent infiltration rates were reduced during the comparatively dry years. Ephemeral stream-channel recharge through autogenic and allogenic processes, the predominant recharge mechanism during wetter periods, was limited to two low-volume events. From visual observations, it appeared that recharge from channel infiltration was equal to or less than recharge from overhead infiltration. Electrical-resistance sensors were able to detect thin films of water on speleothems, including stalactites, ribbons, and stalagmites. These films of water were directly attributed to overhead infiltration of precipitation. Periods of low precipitation resulted in decreased speleothem wetness.
\end{abstract}

\section{INTRODUCTION}

Kartchner Caverns, located in southeastern Arizona, USA, was opened to the public in November 1999 (Fig. 1). Prior to its opening, a baseline investigation of the cave's internal and external climate, geology, and hydrogeology was conducted to aid in identifying future impacts from development. The baseline investigation was conducted in the 1980s and early 1990s, a period that coincided with higher than average precipitation conditions. Results from the baseline investigation are documented in a special issue of the Journal of Cave and Karst Studies (vol. 61, no. 2, 1999). After the initial baseline investigation, observations of precipitation and groundwater levels continued. Concurrent to the opening of the cave to visitation was the onset of drier than average conditions (circa mid-1990s). During the late 1990s, moisture on the cave's formations noticeably declined. The decline was hypothesized to be a consequence of decreased precipitation causing decreased inflow to the cave, the introduction of drier air into the cave with visitors, or both (Rick Toomey, pers. comm.).

During the baseline investigation two primary mechanisms of inflow to the cave were identified as contributors of water to the cave: direct infiltration of overhead precipitation and infiltration of surface runoff in the stream channels that surround the cave (Graf, 1999). The direct infiltration of overhead precipitation has been defined by White (2003) as diffuse infiltration and categorized as autogenic recharge because the recharge water originates over the karst landscape and percolates in place. Infiltration of surface runoff through stream channels is a combination of discrete autogenic recharge (Lerch et al., 2005) and concentrated allogenic recharge (White, 1988, p. 281). In the former, precipitation over the karst landscape is concentrated into losing stream channels and infiltrates into the cave system. Allogenic recharge originates as precipitation over nonkarst areas upstream of the cave system and is concentrated into losing stream channels that are situated adjacent to the cave system. Groundwater inflow from adjacent aquifers was considered a possible source of cave water, but the initial investigators did not observe direct inflow from up-gradient aquifers, except in conjunction with streamflow in adjacent surface channels (Graf, 1999).

The objectives of this study were to determine if the observed declines in water flow on speleothems could be attributed to climate fluctuation and to identify the relative contributions of sources of inflow to the cave system during drier-than-average conditions.

To meet these objectives, it was necessary to use a novel method for detecting the presence of water on speleothems. Electrical-resistance (ER) sensors have been used to determine the presence of flow in ephemeral stream channels based on the ability of water to conduct electricity (Blasch et al., 2002). ER sensors were constructed using modified TidbiT sensors (Onset Corporation, Bourne, Massachusetts) as described by Blasch et al. (2002). ER sensors have been successfully used to monitor streamflow timing in coarse-grained alluvial channels (Blasch et al., 2002) and bedrock channels (Adams et al., 2006) and on 
METHODOLOGY TO ASSESS WATER PRESENCE ON SPELEOTHEMS DURING PERIODS OF LOW PRECIPITATION, WITH IMPLICATIONS FOR RECHARGE SOURCES Kartchner Caverns, Arizona
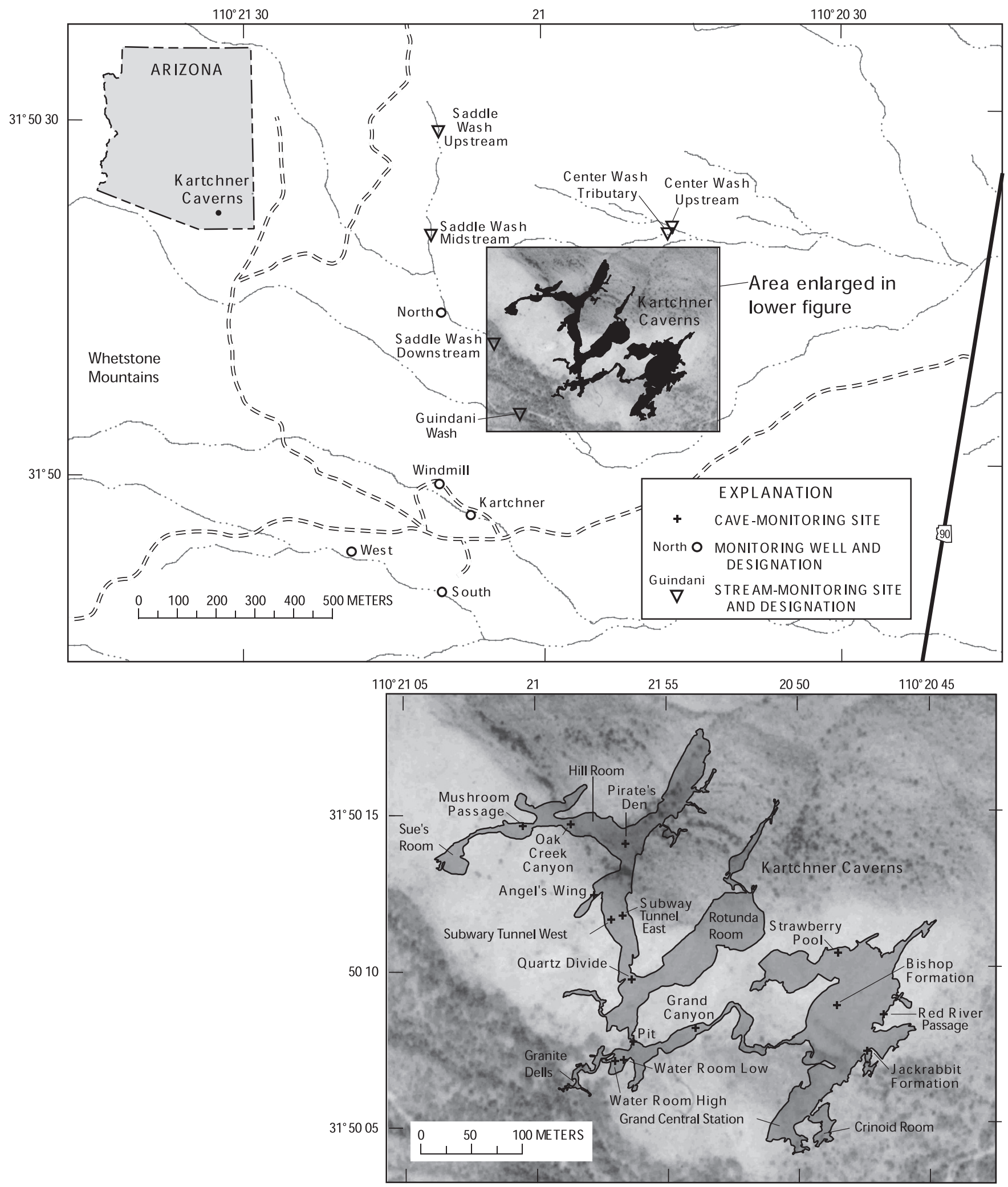

Figure 1. Map of Kartchner Caverns study area and monitoring sites. 
bedrock walls. ER sensors should be useful for monitoring the presence of water within the cave environment, including cave walls, formations, pools, and drainage channels. An additional objective of the study was to evaluate the use of electrical resistance sensors for monitoring formation wetness and water flow within a cave.

\section{STUdy AREA}

Kartchner Caverns is located approximately $75 \mathrm{~km}$ east of Tucson and $30 \mathrm{~km}$ west of Tombstone at the base of the Whetstone Mountains in southern Arizona. A full description of the hydrogeology of Kartchner Caverns State Park was presented by Graf (1999) as part of the Kartchner Caverns State Park Symposium special issue of the Journal of Cave and Karst Studies (vol. 61, no. 2, 1999). Regional geologic history and dating of speleothems and sediments indicates that the cave formed roughly $200 \mathrm{ka}$ ago, with the main speleothem development occurring between then and $70 \mathrm{ka}$ (Hill, 1999). Kartchner Caverns formed at the base of the Whetstone Mountains within a ridge of Mississippianage Escabrosa Limestone. The ridge itself is at the surface of the Kartchner block that has been displaced downward from the Whetstone Mountains to the west, while the San Pedro alluvial basin to the east of the Kartchner block has subsided even farther.

A major fault on its western boundary separates the Kartchner block from the Precambrian-age Pinal Schist and the Whetstone Mountains. The upthrown side of the fault is Pinal Schist, which extends to a greater depth than the Escabrosa Limestone of the Kartchner block on the downthrown side of the fault. The fault is within $0.25 \mathrm{~km}$ of the known extent of Kartchner Caverns. The Pinal Schist is overlain by alluvial sediments, called the granite wash, of Illinoian age (Melton, 1965) that in turn are overlain by the pediment surface called the Whetstone surface. Gray (1967) describes the granite wash as a combination of alluvial sediments, decomposed granite, mud flow, and alluvial fan sediments. The depth of the granite wash, as approximated by Graf (1999), is on the order of tens of meters. Using non-pumping water-level measurements, pump tests, and specific electrical conductivity measurements, Graf (1999) concluded that the groundwater yield in the granite wash is small and that connectivity in the formation is poor. Similarly, groundwater yields in the Pinal Schist are low.

The main basin-and-range fault separating the Kartchner block from the San Pedro alluvial basin to the east was mapped by Graf (1999) using gravity data from Lange et al. (1990). The basin-and-range fault is located less than $0.5 \mathrm{~km}$ from the known eastern boundary of Kartchner Caverns. The San Pedro alluvial basin immediately east of the fault is composed of a course alluvium overlain by granite wash. To the east, the coarse alluvium deposition is replaced by the finer-grained Pliocene and Pleistocene sediments of the St. David Formation. Groundwater levels measured within the St. David Formation indicate flow from the edge of the Whetstones eastward toward the San Pedro River.

Kartchner Caverns is in highly faulted limestone and formed under shallow-phreatic conditions (Graf, 1999). The regional water-table conditions that existed during its formation are no longer present. Depth to water ranges today from tens to hundreds of meters in the vicinity of the cave.

The channels of three ephemeral streams bound the cave (Fig. 1). Guindani Wash originates in the Whetstone Mountains and traverses the southern boundary of the cave from west to east. Center Wash originates on the northern slopes of the cave ridge and flows west to east. Center Wash empties into Guindani Wash northeast of the cave boundary. Saddle Wash originates northwest of the cave and runs along the western and southwestern edge of the cave, eventually merging into Guindani Wash. Both Saddle Wash and Guindani Wash overlie fault boundaries in proximity of the cave.

The explored regions of Kartchner Caverns range in elevation from about $1400 \mathrm{~m}$ near the Red River Passage at the eastern end of the cave to about $1425 \mathrm{~m}$ in Sue's Room at the western end of the cave (Fig. 1). Sediment depths within the rooms vary, so the actual elevations of the bedrock floors are unknown. The stream channels adjacent to the cave system are all above $1432 \mathrm{~m}(4700 \mathrm{ft})$ in elevation, allowing infiltrating water to travel vertically towards the cave system. Saddle Wash passes about 15 meters from the mapped boundaries of the Granite Dells and Guindani Wash passes about 90 meters from the mapped boundaries of Grand Central Station (Fig. 1).

The conceptual flow model for the cave system was originally developed during the baseline investigation of the cave. Components of the flow system were documented by Graf (1999), but important unpublished data still reside with the Kartchner Caverns Cave Resources Unit. As indicated, the primary sources of inflow to the cave originate as overhead precipitation and channel recharge. Graf (1999) noted that the water table is about $200 \mathrm{~m}$ below the known depth of the cave, and thus unsaturated conditions and processes are present.

Graf (1999) estimated that inflow from channel infiltration of ephemeral streamflow events accounted for the majority of the water entering the cave and that the remaining inflow was from direct overhead infiltration of precipitation. Buecher $(1992,1999)$ estimated about $230,000 \mathrm{~L}$ of water $(7.6 \mathrm{~mm}$ over the surface area of the cave) enters the cave through overhead infiltration from precipitation by way of faults, fractures, Darcy flow through permeable beds, and flow down the surface of impermeable, dipping beds (Jagnow, 1999). Using drip studies, Buecher estimated that it took 4 to 12 days for water to percolate from the surface to the ceiling of the cave. This translated into an average groundwater flow 
rate of $15 \mathrm{~m} /$ day through the overhead limestone and pediment.

Three ephemeral stream reaches were identified as contributing areas to the cave through observations, geophysics (Lange et al., 1990, and Lange, 1999), and dye tracers (Buecher, 1992). Fluorescein dye was used in September 1990 to confirm the connection between the ephemeral flow in Saddle Wash downstream from the North well and Sue's Room. Rhodamine WT dye was used in January 1991 to confirm the connection between the junction of Saddle and Guindani Washes and the Granite Dells. Flow from Guindani Wash upstream from the trail was also observed in the Crinoid Room.

Graf (1999) suggested the conditions generally necessary before recharge waters are observable in the cave. These conditions include surface flows in Guindani or Saddle Washes for more than one week and excess soil moisture exceeding $30.5 \mathrm{~mm}$ in one month or $38.1 \mathrm{~mm}$ over two consecutive months as computed by the Thornthwaite potential-evapotranspiration method.

Once water enters the cave, it tends to pond in place and slowly drain through the cave floor. If the flow rate into the cave is higher than the draining rate, ponding will increase until water spills over to neighboring rooms (Graf, 1999). For large flood events this process continues until flow is dispersed throughout most of the cave. Some rooms remain disconnected from the overall flow system due to impermeable units. In general, flow is from west to east, because the surface stream channels are on the western and southern borders of the cave and room elevations within the cave decrease from west to east. Eventually, water flowing through the cave drains through the Red River Passage, at $1400 \mathrm{~m}$ the lowest recorded point in the cave. Graf (1999) estimated an overall drainage rate based on the three largest flood events to be about $22 \mathrm{~L} / \mathrm{min}$, though drainage rates in the rooms vary. It is important to note that the structure of the cave below the mapped rooms (Fig. 1) is unknown. Thus constraints on draining and flow between rooms within the cave are not entirely understood.

\section{METHOD}

Hydrologic parameters were monitored inside and outside of the cave in order to describe the interaction between the surface and subsurface flow system and monitor speleothem wetness.

\section{Outside the Cave}

Monitoring of precipitation, streamflow, and groundwater levels outside the cave started well before this study. Precipitation has been measured about 1 kilometer southeast of the cave and recorded on an event basis using a $20.32-\mathrm{cm}$ bucket rain gauge with an accuracy of $0.25 \mathrm{~cm}$. A second bucket rain gauge with an accuracy of $0.50 \mathrm{~cm}$ was used to collect weekly measurements. The rain-gauge record started in January 1992. In order to quantify flow in an ephemeral stream, continuous monitoring (15-minute interval) in Guindani Wash (Fig. 1) began about January 2000.

For this study, ephemeral streamflow presence was monitored using TidbiT electrical-resistance (ER) sensors and TidbiT temperature sensors installed in stream channels surrounding the cave (Fig. 1). Monitoring began in December 2004, and recording intervals were set to 1 hour. Sensors were installed in perforated PVC housings and tethered to trees adjacent to the channels. Boulders were placed over the sensors to maintain their positions in the lowest portion of the cross-section and to shield the sensors from direct rainfall.

Three sets of ER and temperature sensors were installed in Saddle Wash. The upstream sensors were placed north of Kartchner Hill. The midstream sensors were installed about 275 meters downstream of the upstream sensors, and the downstream sensors were installed about $400 \mathrm{~m}$ downstream of the midstream sensors. The middle set of sensors was placed near a dye injection location used by Graf (1999) during an earlier surface channel recharge investigation.

One set of sensors was installed in Center Wash and an ER sensor was installed in a tributary wash to Center Wash. The unnamed tributary wash originates on the north side of Kartchner Caverns Hill and trends to the northeast into Center Wash.

Groundwater-level monitoring started during the baseline investigation. Monthly groundwater levels were measured in five wells (Fig. 1) during this investigation using a Solinst water level meter. Water temperatures were also measured in the North and West wells on a monthly basis.

\section{INSIDE THE CAVE}

ER sensors and temperature sensors were installed within the cave drainage channels (Fig. 1). To preserve the cave environment, only selected regions of the cave were accessible, and within these regions only prescribed footpaths could be used for sensor installation. Thus some lower-elevation drainage channels were not accessible for monitoring. The lowest-elevation locations in the rooms that could be reached from the foot paths were instrumented. Other placement considerations included consistency with previous dye-trace sites and records of water presence from the baseline investigation. Previous investigations observed entrainment of fines during periods of inflow to the cave. Consequently, sensors were installed about $1 \mathrm{~cm}$ from the sediment surface to avoid deposition of fines on the electrodes.

ER sensors were installed at the bottom of an area that collects flow referred to as the Strawberry Pool. The sensors were placed in a low section of the pool. Water enters the pool from low-flow features and dripping features. ER sensors were installed in the thalweg of a drainage channel called the Red River Passage. The Red 
River Passage is a drain at the eastern edge of the cave. Flow rates in the cave are small enough that the sensors were not put into protective housings. Sensors were installed in the upper and lower regions of the Water Room and in Mushroom Passage exactly where the dyetrace receptors had been placed. Sensors were also installed in the Grand Canyon, the Pit, Quartz Divide, Angel's Wing, Subway Tunnel East, Subway Tunnel West, entrance to the Pirate's Den, and the Hill Room (the sensor location is called Oak Creek Canyon).

A second type of ER sensor that was installed on cave formations was the four-channel external HOBO sensors (Onset Corporation, Bourne, Massachusetts) with open leads. These data-loggers have four channels and sensor wires about $20 \mathrm{~cm}$ in length. The leads of the wires were exposed at the end by $1 \mathrm{~cm}$ and were mounted on the formations using flagging tape (Fig. 2). Each data-logger was housed in a sealed plastic bag containing desiccant.

An initial group of sensors was installed on December 4, 2004, on the Bishop formation and on the Jackrabbit formation. The Bishop formation is a large column that is one of the monumental formations within the cave. The leads on the Bishop formation were installed on a stalactite and in wet and dry alcoves. The Jackrabbit formation is another significant formation mass with a considerable number of soda straws, stalactites, and ribbon features. Leads were installed on a soda straw and a ribbon tip and on the ground below the formation.

Finally, an In-Situ Level Troll 500 pressure transducer was installed in the Subway Tunnel East (Fig. 1), an area with significant ponding, to determine the rate at which water drained. The Subway Tunnel is at a lower elevation and receives flow from upstream rooms.

\section{Results AND Discussion}

\section{Electrical Resistance Sensor Performance Electrical Resistance Sensor (TidbiT)}

The Strawberry Room was one of the wettest areas monitored within the cave on the basis of sensor data and visual observations. The Strawberry Room is easily accessible within the cave, and therefore, more visual observations were obtained during the investigation. These visual observations were used to confirm the presence or absence of water as measured by the ER sensors.

Water was detected by the ER sensor in the summer of 2005 and summer of 2008 (Fig. 3). Four visual observations during the summer of 2005 and 2008 were in agreement with the ER sensor. Seven additional visual observations during dry periods were also confirmed. These data are consistent with successful detections in ephemeral channels previously documented (Blasch et al., 2002). The success of the ER sensors within the cave environment is attributed to the lack of physical hazards such as high streamflow velocities, debris, and scour or deposition processes.
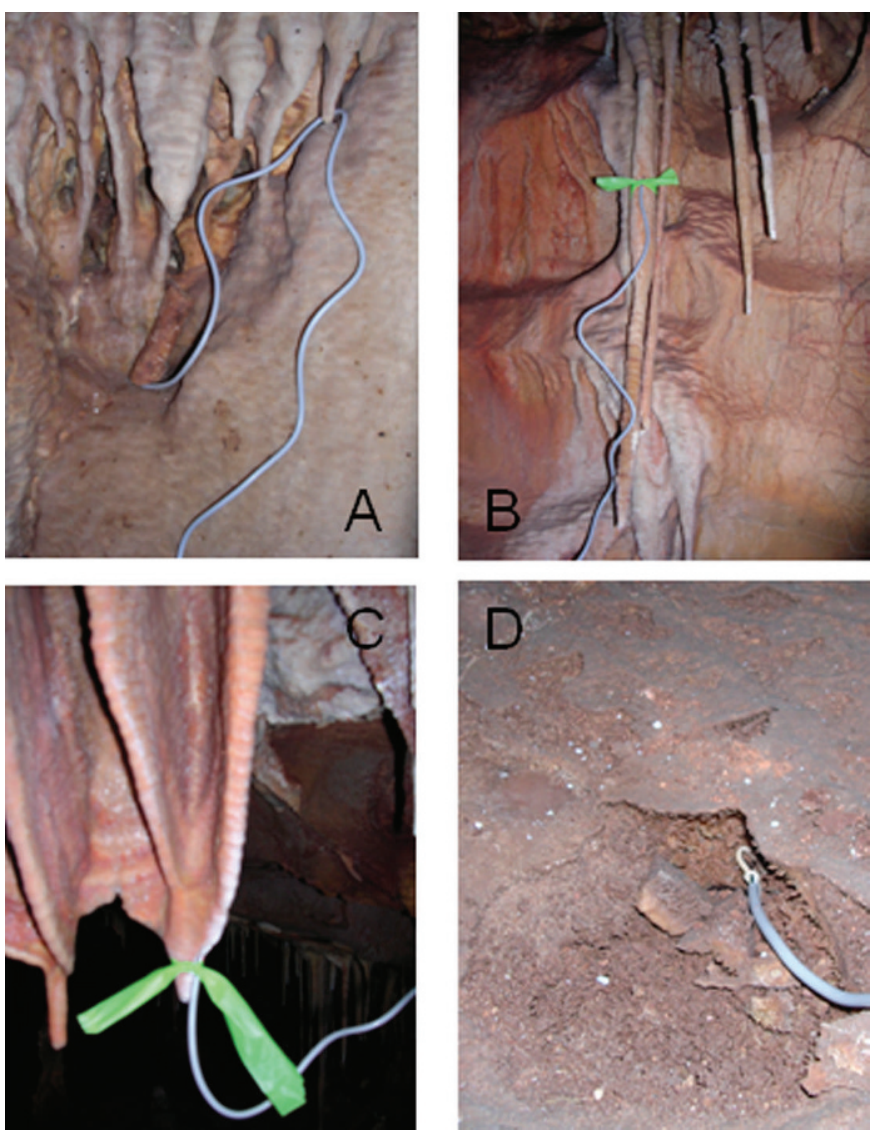

Figure 2. Placement of НОВО electrical resistance sensors on the Bishop Formation (A) and Jackrabbit Formation stalactite (B), ribbon (C), and (D) ground below.

\section{Electrical Resistance Sensor ( $\mathrm{HOBO}$ )}

The HOBO sensors on the Jackrabbit formation recorded data for almost the entire period of study. The data reveals a more complex signature than the TidbiT ER sensors (Fig. 4). This may be attributed to the measurement of thin films of water on the formations or exposure of the circuitry to the humid environment. Voltages recorded before and after disconnecting the sensors from the data-logger, required for downloading, were noticeably different. During data analysis the recorded voltages were adjusted based on the voltage readings prior to the disconnection. With these corrections, the presence of water on the formations is indicated with lower voltage output, implying a higher conductivity.

During the winter of 2005, the spring and summer of 2007, and the summer of 2008 water drops were seen on the tip of the ribbon formation. The HOBO ER sensor recorded a lower voltage (higher conductivity) during these periods as indicated by the light gray points in Figure 4. The sensor on the floor recorded wet and dry conditions consistent with visual observations. The response recorded on the stalactite is not as conclusive (Fig. 4). The decrease in voltage from October 2006 to June 2007 cannot be 
METHODOLOGY TO ASSESS WATER PRESENCE ON SPELEOTHEMS DURING PERIODS OF LOW PRECIPITATION, WITH IMPLICATIONS FOR RECHARGE SOURCES Kartchner Caverns, Arizona
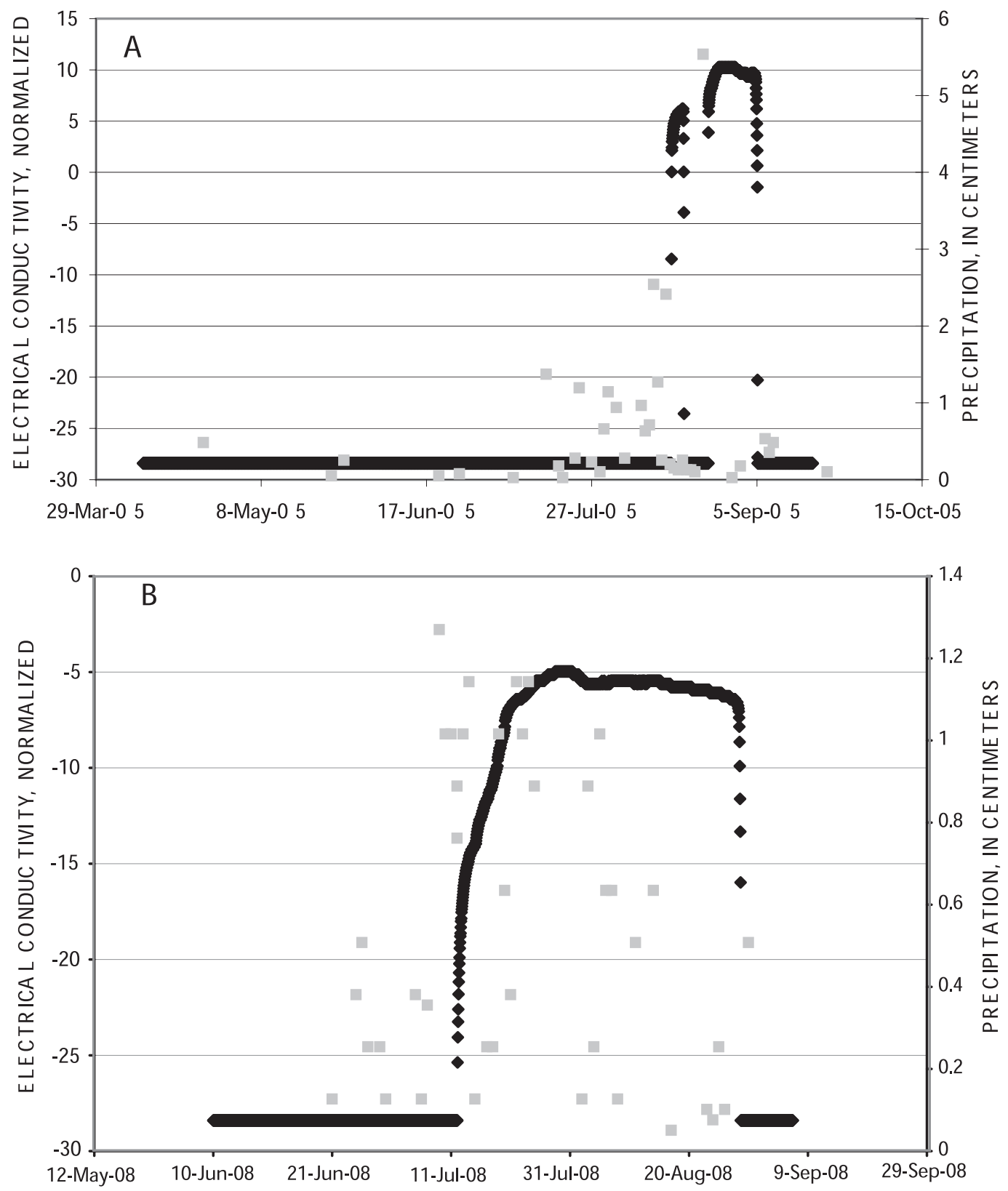

Figure 3. Measurements of normalized electrical conductivity in the pool of the Strawberry Room for (A) 2005 and (B) 2008. Daily precipitation represented by gray squares.

explained. During this time period visual observations indicated the formation was dry.

The sensors on the Bishop formation recorded wetness on the formation consistent with observations until the instruments failed in the humid environment. The last recorded day was April 9, 2005.

Within the cave, the success of the two types of ER sensors differed. The modified TidbiT sensors were well suited for cave channels, ponding areas, and formations with ponding surfaces. The short leads and the weight of the instruments prohibited them from being installed on delicate formations or small fractures. The flexibility of the long leads from the 4-Channel HOBOs was well suited for installation on the delicate formations, but the high humidity of the cave environment was harmful to the HOBO's circuitry and made necessary frequent visits to change the desiccant packaged with the HOBO. One HOBO failed within the first year, likely owing to the highhumidity environment. Output from the HOBOs was also not as clear as output from the TidbiTs. The proprietary nature of $\mathrm{HOBO}$ and TidbiT circuitry prohibited a clear explanation for the difference in readings. For cave channels and ponding situations the TidbiTs performed well, but a combination of the TidbiT's ruggedness and 


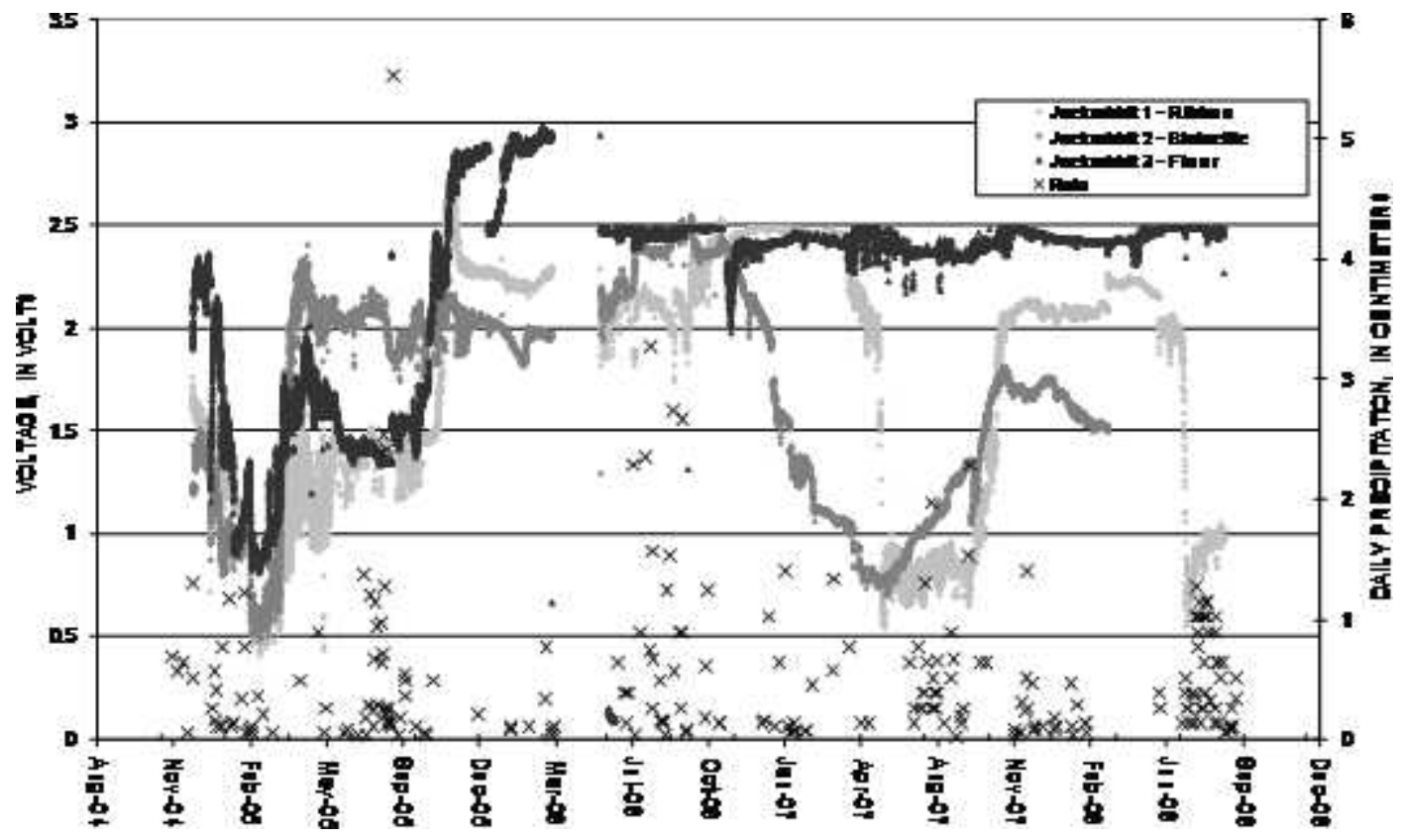

Figure 4. НОВO data for the presence of water on the Jackrabbit Formation. Daily precipitation represented by crosses.

output with the four-channel and long-lead capability of the HOBOs would be an optimal sensor for cave-formation monitoring.

\section{Water Inflow and Movement in the Cave System External Cave Environment}

Climate conditions at Kartchner Caverns were drier than the long-term mean. Mean annual precipitation monitored at Tombstone, Arizona, (National Climatic Data Center, 2008a) was $36 \mathrm{~cm}$ from 1900 to 2005 (Fig. 5).
Rainfall measured at Kartchner Caverns from 1992 to 2007 averaged $34 \mathrm{~cm}$. During this study, annual rainfall values at Kartchner Caverns were 32, 31, and $28 \mathrm{~cm}$ per year, respectively. This translates into a reduction of 6 to 18 percent from mean annual rainfall. The Palmer Drought Severity Index (PDSI) for the southeast region of Arizona was used as an indicator of dryness and moisture storage (Fig. 6). PDSI values were obtained from the National Oceanic and Atmospheric Administration's National Climate Data Center (National Climatic Data Center,

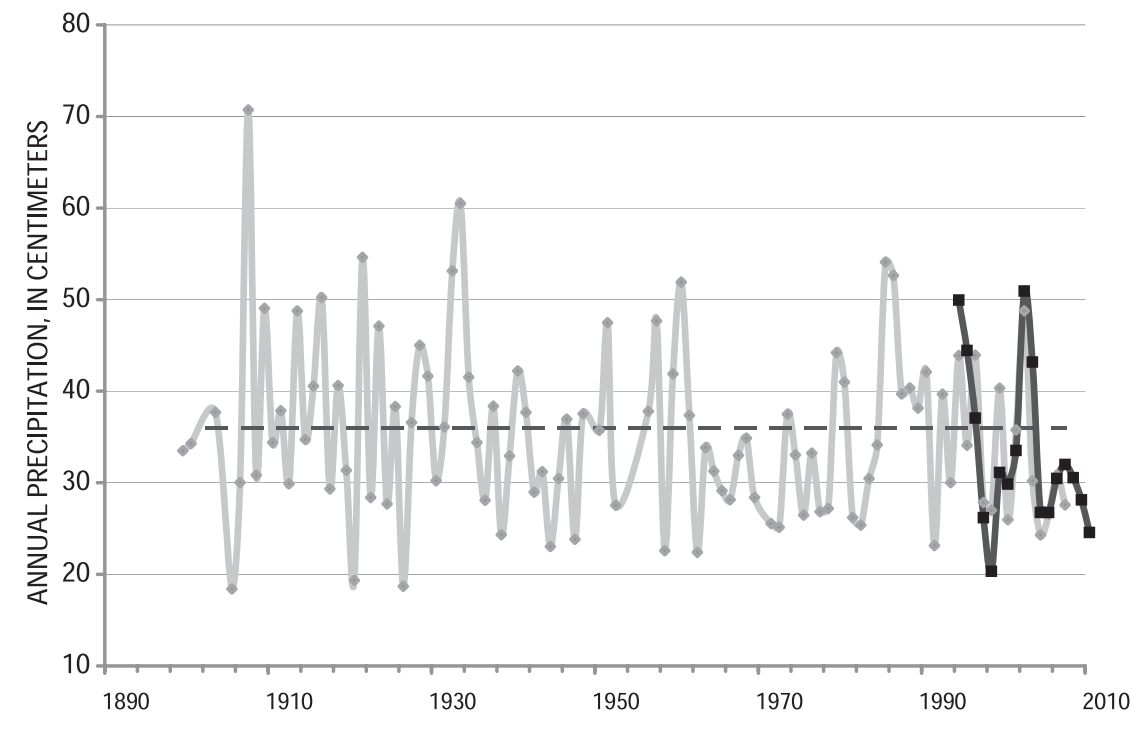

Figure 5. Annual precipitation for Tombstone, Arizona, (gray diamonds) and annual precipitation for Kartchner Caverns (black squares). 
METHODOLOGY TO ASSESS WATER PRESENCE ON SPELEOTHEMS DURING PERIODS OF LOW PRECIPITATION, WITH IMPLICATIONS FOR RECHARGE SOURCES Kartchner Caverns, Arizona

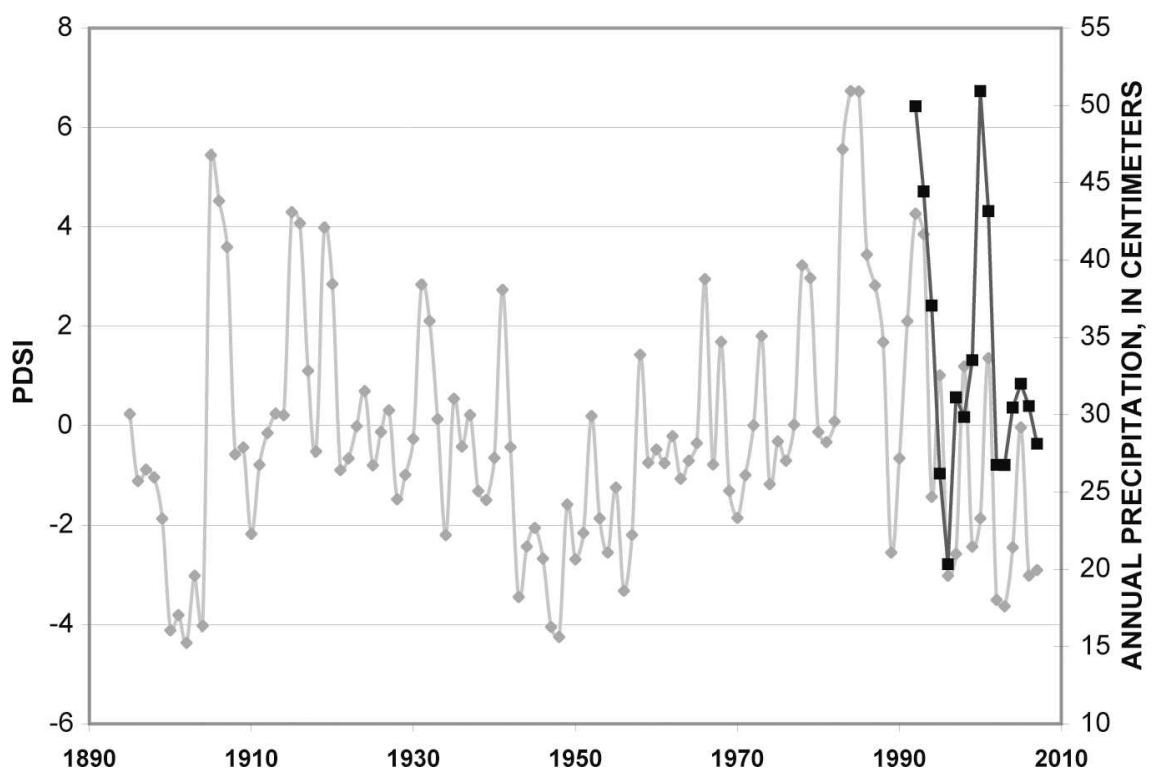

Figure 6. The Palmer Drought Severity Index (PDSI) for the southeast region of Arizona (National Oceanic and Atmospheric Administration's National Climate Data Center, 2008b) and annual precipitation for Kartchner Caverns (black squares).

2008b). Since 1994 the average annual PDSI has risen above normal only three years (1995, 1998, and 2001). The initial baseline investigations were conducted after six years of above normal values (1982-1987). During the baseline investigation from 1988 to 1992 , the years 1989 and 1990 were below normal.

Ephemeral streamflow events, previously identified as the predominant source of recharge to the cave, are produced by high precipitation rates. There were no data on streamflow events collected during the baseline study in the early 1990 s to compare. Streamflow events were detected in the ephemeral streams about nine times per year in Saddle Wash and about five times per year in Central Wash (Fig. 7). With the exception of the event on December 1, 2007, in upstream Saddle Wash, the remaining flow events occurred during the wet season (July-September) or during the fall (October-November). The wet season is a period of above-average precipitation (24 $\mathrm{cm}$ for the three-month period) due to high-intensity, convective rain storms. Average streamflow event duration for Saddle Wash (midstream) was 79 hours and the median event duration was 8 hours. Average event duration for Center Wash (main stem) was 27 hours and the median event duration was 5 hours.

Ephemeral streamflow events in Guindani Wash were rare. Streamflow events did not occur during 2003, 2004, 2006, or 2007. There were seven streamflow events in 2000 and two events in 2001. There was insufficient data for 2002. One flow event was detected in 2005 from 14-31 August, 2005 (Fig. 7). This event was associated with a measured rainfall of $2.4 \mathrm{~cm}$ on August 14, 2005, and $5.5 \mathrm{~cm}$ on August 23, 2005. Flow was observed during the July 22,
2008 event, but the gauge sustained damage during this high-flow event and the data were lost.

On the basis of rainfall and streamflow data, a rainfall intensity of $1.2 \mathrm{~cm} \mathrm{~d}^{-1}$ at Kartchner Caverns is generally required to generate runoff in the surface channels. Lower intensity rainfall events of $0.6 \mathrm{~cm} \mathrm{~d}^{-1}$ generated runoff if the event succeeded several days of rainfall. Winter storm intensities generally were not high enough to produce runoff during this period of study, though Graf (1999) observed earlier winter streamflow events.

Based on Graf's (1999) personal communication with Robert Buecher, one of the requirements for observed flow in the cave was at least one continuous week of ephemeral streamflow within Guindani or Saddle Wash. From December 2004 through September 2008 there was only one event in Saddle and Center Washes that was more than a week in duration. The 2008 wet-season event that started on July 22 caused flow for 36 days in Saddle Wash. Guindani Wash had flow that exceeded one week during this same time period, as well as a 14-day event during September 2005.

The full extent of the cave both laterally and vertically is unknown. Recent geophysical exploration supports the existence of large voids the size of the Rotunda Room to the west of the explored cave perimeter (Dale Rucker, personal communication, October 2007). Existence of these voids and their connection to Kartchner Caverns has not been verified. Voids between the known cave system and the adjacent washes could be important for the transmission of water from the washes into the known cave system. The size and location of voids affects the storage capacity and can reduce the volume and rate of flow into the 


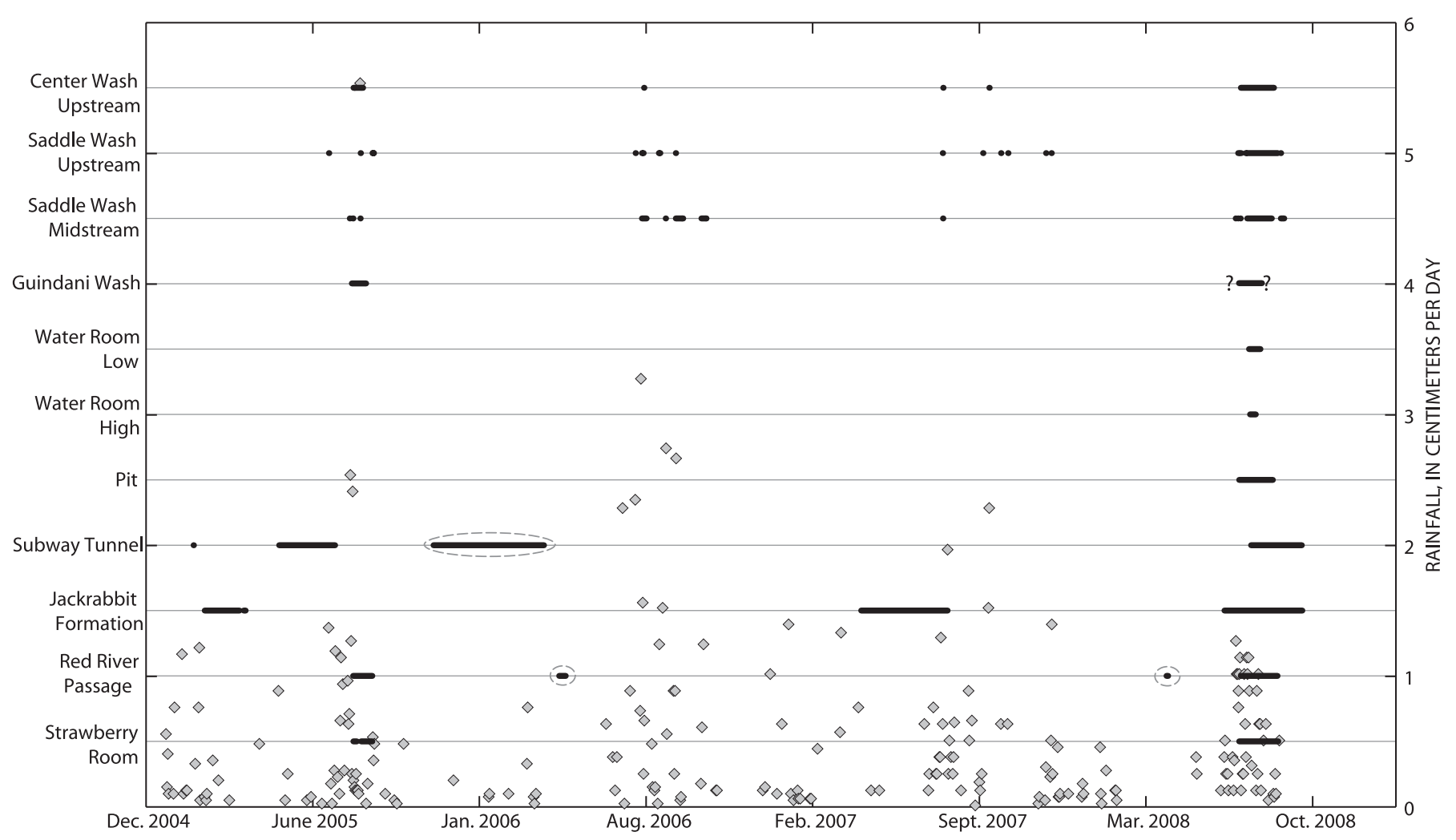

EXPLANATION

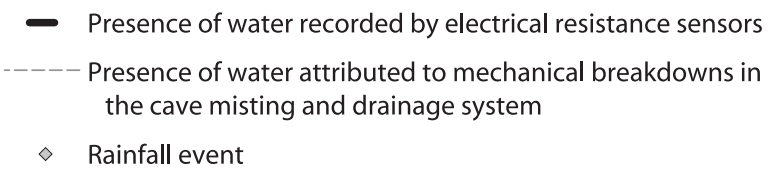

Figure 7. Water occurrence within the ephemeral stream channels outside the cave and formations and rooms within the cave, Kartchner Caverns, Arizona. Only monitoring sites with a nearly full period of record are shown. Daily precipitation totals represented by gray diamonds.

currently mapped and monitored portions of the cave system.

Groundwater levels in the adjacent granite wash and Pinal schist aquifers declined during the period of this investigation, but water levels remained higher than the lowest cave elevations monitored during the study (Fig. 8). Water levels were about 1 to 10 meters lower than historic water levels measured in 1995 and 2000. Graf (1999) analyzed historic water levels and concluded that groundwater inflow to the cave from the adjacent aquifer was negligible with the exception of infiltration over the fault boundaries underlying Saddle and Guindani Washes. Groundwater inflow to the cave was not observed during this investigation.

\section{Internal Cave Environment}

Measurements of humidity and temperature obtained from the Kartchner Cave Resources Unit shows a nearly undetectable increase in temperature and humidity for the Strawberry Room from September 2000 to September 2008
(Fig. 9). A general analysis of trend shows temperature increased from $21.44{ }^{\circ} \mathrm{C}$ to $21.67{ }^{\circ} \mathrm{C}$ and humidity increased from 97.9 percent to 98.2 percent. Over the same time period, measurements at Red River Passage showed an increase in temperature from $21.28{ }^{\circ} \mathrm{C}$ to $21.44{ }^{\circ} \mathrm{C}$ and almost no change in humidity when outliers are removed.

Water was not detected in the channel observation sites within the Mushroom Passage, Oak Creek Canyon, intersection with the Pirate's Den, Angel's Wing, or the Grand Canyon for the duration of the investigation. Water often observed in footprints along the paths within some of these rooms probably came from infiltration of rainfall and dripping from the ceiling. The ponding was not significant enough in these rooms to cause runoff to the drainage channels being monitored.

The Strawberry Room is on the northeastern edge of the cave and is the farthest monitoring site from the surface stream channels. Water was noticeable in the summer of 2005 and the winter and summer of 2008. Pooling in this room due to rainfall occurred within one day of a rainfall 


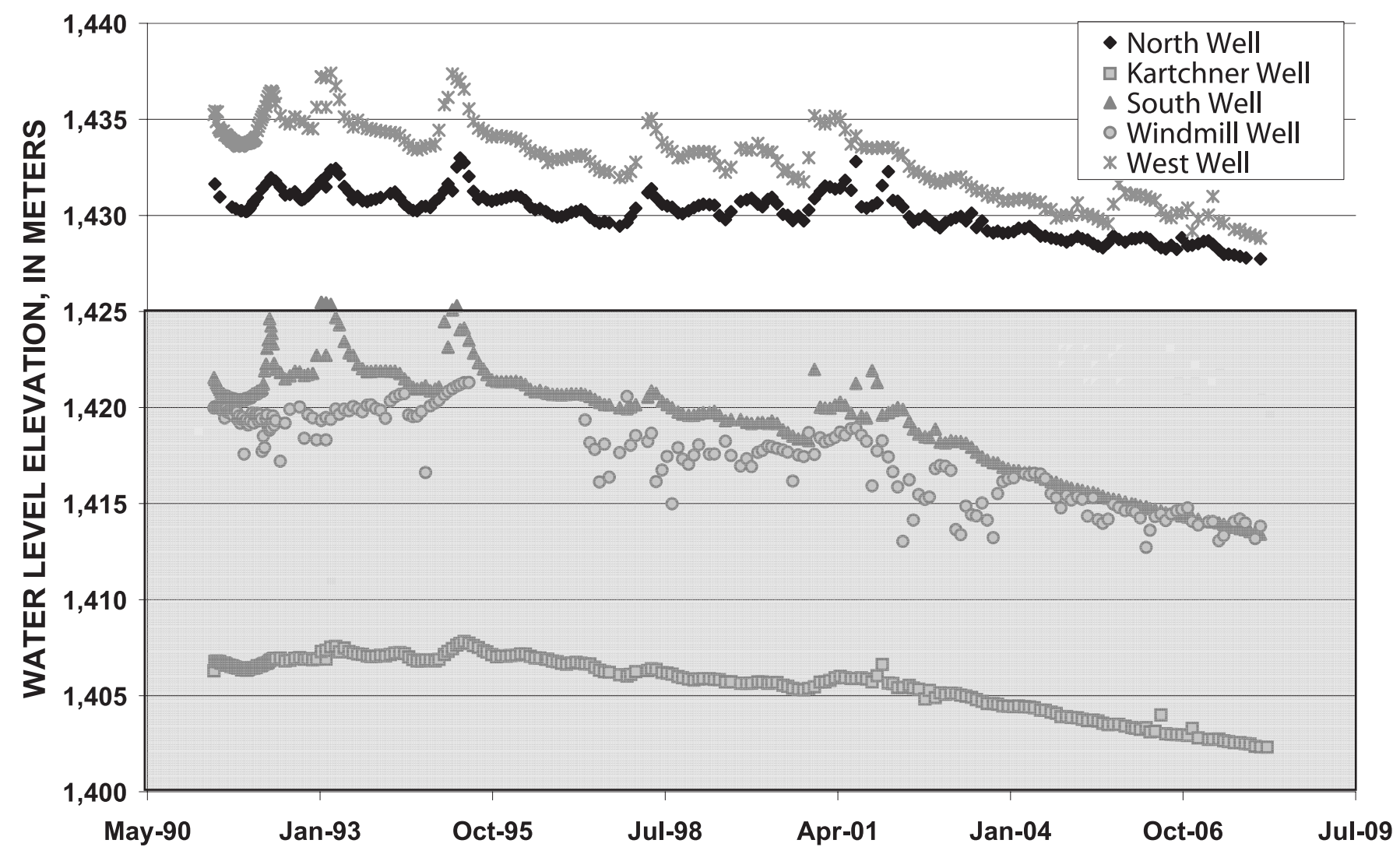

Figure 8. Groundwater levels (elevations) for wells adjacent to Kartchner Caverns. The patterned box indicates known depths of the cave system.

event. On August 15, 2005, ponded water was detected. This followed seven days with rain and a wet July. In particular, August 11 and August 14 both had rainfalls of about $2.5 \mathrm{~cm}$. On August 18 the ponded water was no longer present. However, a rainfall event on August 23 produced about $5.5 \mathrm{~cm}$ over the cave system. Within one day (August 24), another pulse of water pooled in the Strawberry Room (Fig. 3A). The longest recorded ponding occurred from July 12, 2008, to August 28, 2008 (Fig. 3B).

Ponded water was recorded in the Red River Passage in September 2005 and April 2006. During the winter of 2007/ 2008 there was evidence of water, but the ER sensor had failed. Flow also was recorded in July and August of 2008 for a period of 44 days. Water detected at the Red River Passage during September 2005 and the September 2008 heavy-rainfall events was probably a combination of rainfall and infiltration from Guindani Wash (Fig. 7). The Red River Passage showed periods of wetting during April 2006 and April 2008 when there was no rain or streamflow activity. Personnel at Kartchner Caverns suspect that a floor sump near the Red Passage overflowed, discharging water into the Red River Passage. The floor sump drains water that is introduced through a plumbing system to clean foreign contamination from the paved trails.

The summer wet season of 2008 was the only time water was recorded by the Water Room High and Water Room
Low sensors and in the Pit. Given these rooms' proximities to Saddle Wash, this water is likely to have originated as infiltration from this steam during the long period of flow.

The record of water detected in the Subway Tunnel was not consistent with the precipitation or streamflow records (Figs. 7 and 10). The source of the water was traced to leaking misters in the Rotunda Room. Several misters had been installed at the entrance of the cave to reduce foreign contamination such as lint from being deposited into the cave by visitors. Leaking mister sprayers were replaced December 14, 2005, January 21, 2005, and March 30, 2005. In each case the water level immediately declined in the Subway Tunnel after the replacements. These events provided the data to conclude that a flow of water into the Subway Tunnel from the Rotunda Room occurred through sediments, thus establishing a hydraulic connection between these rooms. Additionally, in order for water to travel from the Rotunda Room to the Subway Tunnel, the horizontal rate of travel had to be higher than the vertical drainage rate of the sediments within the Rotunda Room. The water level in the Subway Tunnel drops approximately $0.8 \mathrm{~cm} / \mathrm{d}$, according to the pressure transducer, when no water is flowing into it.

\section{Climate Impacts and Future Considerations.}

Compared to the period of the baseline investigation, the magnitude of recharge observed within Kartchner 


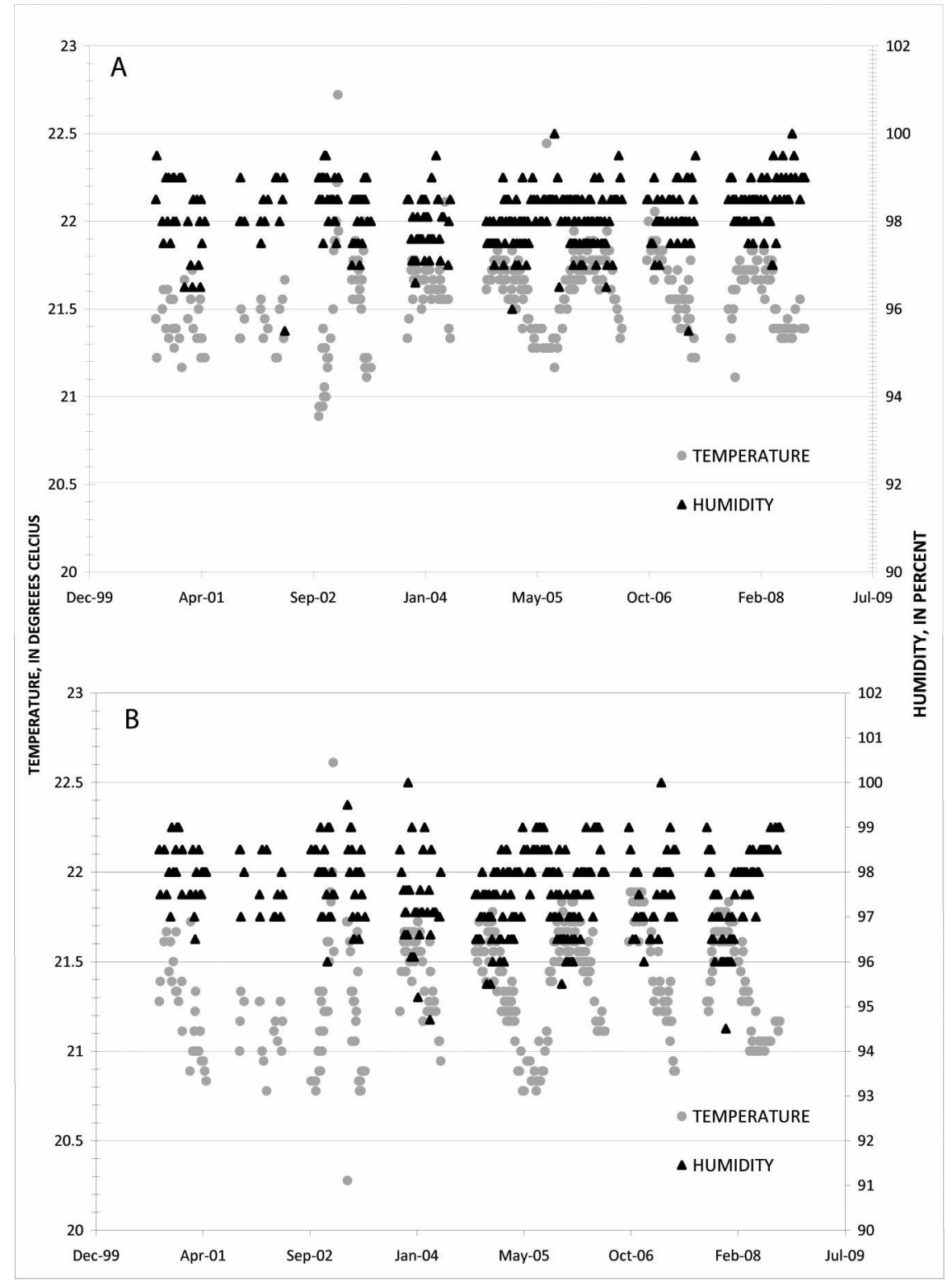

Figure 9. Humidity and temperature for the Strawberry Room (A) and the Red River Passage (B).

Caverns from both ephemeral streamflow infiltration (autogenic and allogenic recharge) and direct infiltration of precipitation (autogenic recharge) was less. There are not sufficient data to compare the total volume of water from each of these recharge mechanisms, but through visual observations the amount of water introduced through streamflow infiltration (two possible events over 44 months) was not noticeably higher than the amount introduced by direct infiltration. This would have to be verified with a more detailed study, but is in contrast to the results from the baseline period of above average rainfall.

During this investigation, autogenic recharge from direct infiltration occurred throughout the entire period of the investigation. One consideration for cave manage- ment is to identify the higher and lower permeability fracture zones overlying the cave through the continued use of ER sensors and drip monitoring. To aid in this endeavor, precipitation measurements should be initiated above the cave. These data would be useful for producing a detailed assessment of vulnerability of formations to lowrainfall years.

Both climate fluctuations and the opening of the cave to visitors are likely contributing to changes in water and water vapor transport within the cave, but the data above show that decreased precipitation and overhead infiltration of water into the cave contributes directly to the reduction of water on the formations throughout the cave. Even if opening of the cave is increasing the inflow of dry air near the entrance, humidity measurements near the formations 
METHODOLOGY TO ASSESS WATER PRESENCE ON SPELEOTHEMS DURING PERIODS OF LOW PRECIPITATION, WITH IMPLICATIONS FOR RECHARGE SOURCES Kartchner Caverns, Arizona

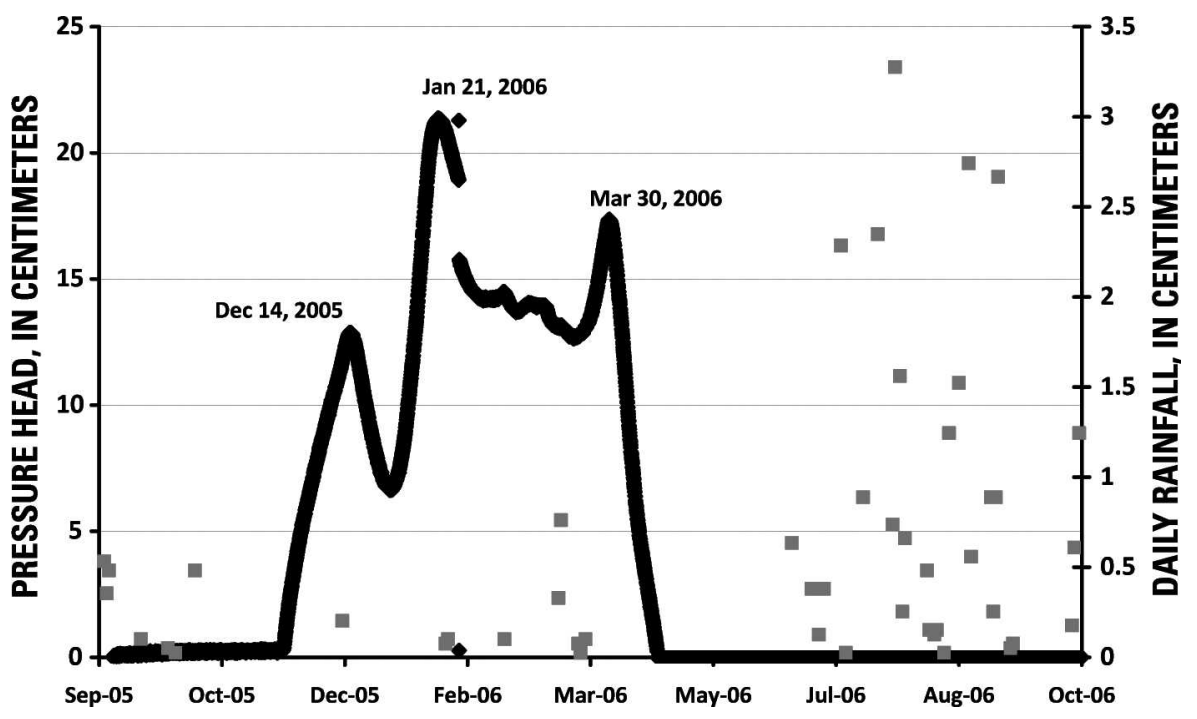

Figure 10. Pressure-head (depth) measurements of ponded water in the Subway Tunnel. Daily precipitation shown as gray squares.

show from no change to a slight increase. While more detailed air-inflow studies are in progress at the cave entrance, humidity measurements, speleothem drip-rate measurements, and ER measurements should continue to be conducted throughout the cave for assistance with future visitor management.

\section{CONCLUSIONS}

During this investigation, recharge of water to Kartchner Caverns from surface channel infiltration, overland infiltration from precipitation, and groundwater inflow was monitored using electrical-resistance sensors, temperature sensors, pressure transducers, and groundwater levels. The investigation coincided with a period of lessthan-average rainfall, permitting the comparison of results from this study to the baseline investigations at Kartchner Caverns conducted during a period of higher-than-average rainfall. Monitoring of ephemeral streamflow in the surface channels overlying the cave and the presence of water in the cave itself indicated that the primary difference between wet and dry climate periods is the almost complete absence of any surface channel infiltration recharging the cave system during dry periods. Additionally, overhead autogenic recharge from infiltrating precipitation decreased during drier periods. Humidity measured in the cave at the monitoring points away from the cave entrance was consistent with wetter periods. This would indicate that, although the amount of water flowing on speleothems decreased during the drier period, existing drops on cave speleothems do not more readily evaporate. Finally, electrical-resistance sensors proved valuable for wetness detection on speleothems and within cave drainage channels. Encapsulated circuitry was necessary for instrument integrity within the humid cave environment.

\section{REFERENCES}

Adams, E., Monroe, S., Springer, A., Blasch, K.W., and Bills, D.J., 2006, Electrical resistance sensors record spring flow timing, Grand Canyon, Arizona: Ground Water, v. 44, no. 5, p. 630-641. doi: 10.1111/j.1745-6584.2006.00223.x.

Blasch, K., Ferré, P., Christensen, A., and Hoffmann, J.P., 2002, A new field method to determine streamflow timing using electrical resistance sensors: Vadose Zone Journal, v. 1, p. 289-299.

Buecher, R.H., 1992, Final report, environmental and geologic studies for Kartchner Caverns State Park, Arizona Conservation Projects, Inc., $328 \mathrm{p}$.

Buecher, R.H., 1999, Microclimate study of Kartchner Caverns, Arizona: Journal of Cave and Karst Studies, v. 61, no. 2, p. 108-120.

Graf, C.G., 1999, Hydrogeology of Kartchner Caverns State Park, Arizona: Journal of Cave and Karst Studies, v. 61, no. 2, p. 59-67.

Gray, R.S., 1967, Petrography of the Upper Cenozoic non-marine sediments in the San Pedro Valley, Arizona: Journal of Sedimentary Petrology, v. 37, p. 774-789.

Hill, C.A., 1999, Overview of Kartchner Caverns, Arizona: Journal of Cave and Karst Studies, v. 61, p. 41-43.

Jagnow, D.H., 1999, Geology of Kartchner Caverns State Park, Arizona: Journal of Cave and Karst Studies, v. 61, no. 2, p. 49-58.

Lange, A.L., 1999, Geophysical Studies at Kartchner Caverns State Park, Arizona: Journal of Cave and Karst Studies, v. 61, no. 2, p. 68-72.

Lange, A.L., Gustafson, E.P., and Walen, P.A., 1990, Geophysical field studies at Kartchner Caverns State Park, Arizona, Arizona Conservation Projects, Inc, $49 \mathrm{p}$.

Lerch, R.N., Wicks, C.M., and Moss, P.L., 2005, Hydrologic characterization of two karst recharge areas in Boone County, Missouri: Journal of Cave and Karst Studies, v. 67, no. 3, p. 158-173.

Melton, M.A., 1965, The geomorphic and paleoclimatic significance of alluvial deposits in southern Arizona: Journal of Geology, v. 73, p. 1-38. doi: 10.1086/627044.

National Climatic Data Center, 2008a, Climate Summaries, http://www. wrcc.dri.edu/summary/climsmaz.html, [accessed September 14, 2008].

National Climatic Data Center, 2008b, U.S. Temperature-Precipitation-Drought Index (DSI-9640), http://www7.ncdc.noaa.gov/CDO/ CDODivisionalSelect.jsp\#, [accessed September 14, 2008].

White, W.B., 1988, Geomorphology and Hydrology of Karst Terrains, New York, Oxford University Press, 464 p.

White, W.B., 2003, Conceptual models for karstic aquifers: Speleogenesis and Evolution of Karst Aquifers , v. 1, no. 1, 6 p., re-published from:, Palmer, A.N., Palmer, M.V., and Sasowsky, I.D., eds., 1999, Karst Modeling, Karst Waters Institute Special Publication 5, p. 11-16. 